\title{
Lessons learned from the preparation of the flood risk management plans on the Seine basin and perspectives
}

\author{
Dr Sébastien Dupray ${ }^{1, a}$, Caroline Lavallart ${ }^{1}$, Elodie Salles ${ }^{1}$, Isabelle Vignasse ${ }^{1}$ \\ ${ }^{1}$ Regional directorate of Ile-de-France for environment and energy, 10 rue Crillon, 75004 Paris France
}

\begin{abstract}
The present paper presents how the flood directive has been implemented on the Seine and coastal rivers of Normandy basin. It presents the various steps and details the elaboration of the basin flood risk management plan (PGRI). Though out of the scope of the present paper, the new responsibility in term of flood prevention given to local authorities will be briefly introduced and discussed with reference to the implementation of the flood directive.
\end{abstract}

\section{A brief presentation of the Seine and coastal rivers of Normandy basin}

The Seine-Normandy river basin with $97000 \mathrm{~km}^{2}$ covers $18 \%$ of France. It includes $70,000 \mathrm{~km}$ of water courses with the river Seine and its affluents, including Oise, Marne and Yonne. With $600 \mathrm{~km}$ of coastlines over the Channel, from Mont Saint-Michel to Bresles, it includes numerous coastal rivers including Touques, Dives and Orne. It covers 29 departments and the regions of Normandy, Ile-de-France, Nord-Pas-de-Calais Picardie, Champagne-Ardennes, Bourgogne and Centre as well as a part of Britanny and Lorraine [1] representing around 20 millions persons and $40 \%$ of the economic activity.

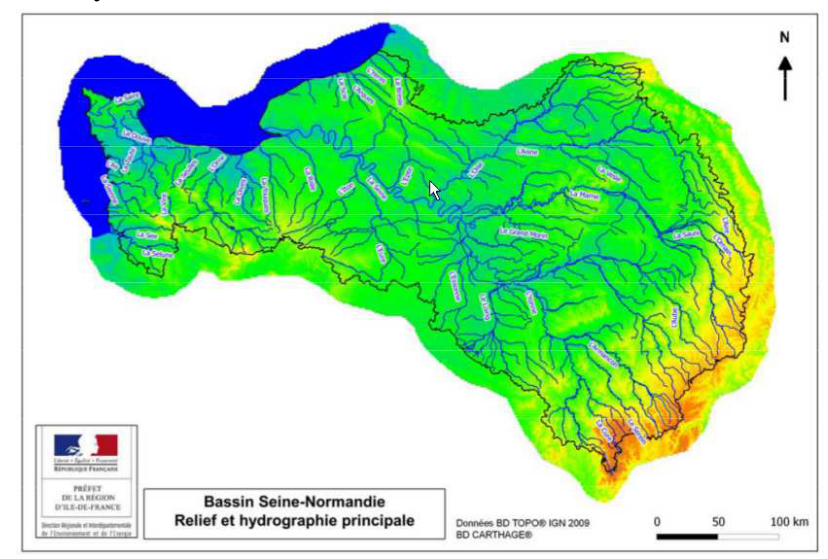

Figure 1. Map of the basin displaying the main rivers (in blue) and a simplified topography (from green to orage) (source [2]).

With 4.8 million of persons and 3.0 million jobs living in flood prone area, it is significantly exposed to flooding hazards. One fourth of the cities of the basin have more than $30 \%$ of their population exposed to river flooding. In the particular situation of coastal cities, up to 200000 habitants are exposed to coastal floods and some cities have up to $80 \%$ of their population exposed to coastal floods [2].

The basin has not been exposed to major flood recently as the latest event are respectively, 2011 for water-table flood in Normandy, 1997 for run-off flood in Normandy, 1990 for coastal floods and 1910and 1955 for Seine river flood (as well as 1995 on its affluent Oise).

Not only a physical and geographical entity, the basin has been acknowledged as administrative scale of action by the law 64-1245 of the 16th December 1964 [3] that created the comité de bassin (also sometime called the basin parliament on water) and the agences financières de bassin, now agence de l'eau (ie. basin financial agency). The relevance of this scale of management has confirmed over time [4] as well as by the law 2010-788 of the 12th of july 2010 portant engagement national pour l'environnement (ie. with value of national commitment for the environment), which accounts for the transposition of the flood directive in the French law.

\section{A well established national framework}

The French government decided to set a framework for the application of the EU Flood directive that is set in the law (in particular at article L. 566-4 of the code for environment) and known as la stratégique nationale pour la gestion des risques d'inondation, SNGRI (ie. the national strategy for the management of flood hazards). It was prepared officially approved on the 7th October 2014 by the minister of interior affairs, the minister in charge of environment, the minister of agriculture as well as the

\footnotetext{
${ }^{\mathrm{a}}$ Corresponding author: sebastien.dupray@developpement-durable.gouv.fr
} 
minister in charge of housing and planning. This strategy

[5] defines the 3 main primary objectives :

- increase the safety of the populations exposed,

- rapidly stabilise and in, at mid-term, reduce the cost of damages due to flood risks,

- reduce significantly the time required for territories to come back to normal,

A framework of actions with 3 guiding principles is set up (solidarity, subsidiarity and synergies between the various policies, prioritisation and continous improvement) and the four challenges to adress are identified :

- developing governance and ownership of actions,

- durable planning for territories,

- better knowledge for better action,

- learning to leave with flooding hazard.

It also set in place indicators as means to evaluating progress achieved.

These elements are the testimony of a high level public commitment to tackle the challenges associated to flood management, knowing in particular that such framework does not necessary exist for other public policies. It sets up a ground and guidelines for a coherent implementation in each basin. We would like to stress here that SNGRI was prepare by the commission mixte inondation, CMI (ie. the mixed commission for inundation) that is a dedicated commission emerging from the commission national de l'eau (the national water commission in charge of all water related policies) and the commission national pour la prévention des risques naturels majeurs (ie. the national commission for prevention of major natural hazards) that was installed the $12^{\text {th }}$ july 2011 . The dual roots of that commission shows the direction for a deep integration of flood and water policies.

The transcription in the french law of the flood directive [6] identified the various steps to implement the flood directive at the basin scale :

- knowledge : production of a preliminary evaluation of flooding hazard (EPRI) for 2011;

- priority : identification territories exposed to important flooding hazard (TRI) for 2012 ;

- further knowledge : for each TRI, a map of flooding surfaces, heights (for 3 typical events including climate change) and exposure, for 2014 ;

- plan and evaluate : for each TRI, a local flood management strategy (SLGRI) for 2016.

The basin flood risk management plan (in french plan de gestion du risque d'inondation, PGRI) is a key milestone that is introduced by the law at article L. 566-7 of the code de l'environnement and had to be approved before the end of 2015. The duration of the plan is six years and this first edition will be revised 2021.

\section{Governance and previous steps at the basin level}

\subsection{Governance}

To understand the context in which the PGRI was prepared, it is necessary to present to key structures of governance on water and flood management in the SeineNormandy basin and to come back on the preliminary steps of PGRI.

As stated earlier, the comité de bassin is a key structure of governance for the water policy. It deals with the various aspects of water including quality, quantity, aquatic environment, for both inland and coastal waters, including accompanying the implementation of other water related directives. For that purpose, several technical commissions are active (the commission on prospective, the commission on environmental matters and the commission on coast and the sea) as well as task groups mainly dealing with matters of concern for some sectors of activities (such as water and agriculture, water and industry, water and local communities). The secretariat of all these commissions is ensured by the agence de l'eau that notably is in charge of collecting various taxes on water and using them to finance the implementation water policies as well as to carry out studies and monitoring. At the time of implementing the flood directive (and till 2015), no commission was specifically in charge of flood management though that topic was dealt with when required by the prospective commission and the water and local communities group, in particular as the implementation of the water directive dealt with some aspects related to flooding. In addition, funding priority was specifically given to water related matters and marginally to flood related topics. As a consequence, the comité de bassin preferred not to be the governance body for implementation of the flood directive.

Consequently, the comities of the Plan Seine (ie. Seine river scheme) was used to implement the flood directive in the basin. Indeed, plans grand fleuve (ie. schemes for main rivers) where introduced in 1994, starting on the Loire river with the Plan Loire Grandeur Nature (ie. a scheme for a natural river Loire) announced by Michel Barnier, minister for environment at the time. These schemes aim at providing a basin coherence as well as a holistic approach to the river policies. In particular, they includes aspects dealing with nature and environment, economical development of local territories as well as flood prevention [7]. In particular from 2007, a plan Seine has been set in place with four key orientations : flooding, water quality, aquatic environment as well as a project of territories from the Seine source to the channel. It notably includes a financial contract between the government and regional council for 2007-2013 that deals with financing flood prevention actions [8].

The steering committee of the plan Seine was used as the core for a steering committee on the flood directive : it was developed with additional member to correctly 
address the stakes identified by the Directive, in particular cultural heritage and economic activities.

To prepare all work of the steering committee, a technical committee composed of the government directorates (basin, region and department) was composed. The agence de l'eau and the 2 major EPTB where also part of the task force. EPTB are public organisations at the scale of the basin, in charge of coordinating action on water and floods [9]. The secretariat was ensured by the Seine Normandy delegation that is also in charge of representing the government directorates in the basin commissions and instances.

\subsection{Steps prior to the PGRI}

\subsection{1 preliminary flood risk assessment EPRI}

The preliminary risk assessment required by the flood directive was produced in 2011 and formally adopted on the $20^{\text {th }}$ december 2011 [2]. It was the very first step of gathering flooding related information at the basin scale. The various districts selected aimed at ensuring, by construction, coherence with the water directive as well as effective exchange with the stakeholder used to exchange on water related topic : rivers of lower Normandy (mainly coastal), downstream Seine (with some coastal rivers), rivers of Ile-de-France (mainly the seine in Paris with some affluents), upstream Seine, Oise valley and Marne valley. The complete gathering of known information on flooded areas allowed the production of what was called the approached envelop of potentially flooded area (EAIP) for both river flood and coastal flood. It mainly combined information from local planning documentation (generally based on modelling or processing of known historical data), more general flooding atlas maps (based on interpretation of geomorphological data) as well as processing topographical data in coastal areas.

It was then the basis to identify the potential impact of floods on population (including known population, housing and hospitals), economical activities (including job, buildings, rail and road networks), environmental risks (including nuclear installation, activities covered by SEVESO or IPPC directives, larger sewer treatment plant and various environmentally protection areas) as well as cultural heritage (indirectly through building classification).

5 years after this very first task, it appears that it was an essential phase although it mainly remained a technical one. New document available to stakeholder, the status of the EAIP map was naturally questioned and it was required to explicitly warn that it was only a technical, interim map, not to be used for detailed planning or design activities, nor at scale greater than 1/100 000. It was an essential step forward that allowed for the very first time ever to have a global and consistent view of areas prone to river and coastal floods (although not extensive) as well as a very first estimation of the basin vulnerability. For this very first EAIP, accounting for run-off was a challenge. Secondly, evaluation of vulnerability was technical and its financial evaluation limited at this stage. It thus triggered some initiatives such as the OECD reviews of risk management policies on Paris vulnerabilty [10].

\subsubsection{Important territories exposed to flooding risk (TRI)}

In order to allow a tiered approached of risk and as a response to article 5 of the flood directive, critical territories where identified through analysis of the stakes exposed in the EAIP map :

- population count in the EAIP greater than 15000 ,

- $\quad$ surface of one storey building in EAIP greater than $110000 \mathrm{~m} 2$,

- job count in the EAIP greater than 10000 ,

- $\quad$ surface of construction for economic activities in EAIP greater than $550000 \mathrm{~m} 2$.

31 urban areas responded to one criteria at least and 16 to all of them : Caen, Dives - Ouistreham, Cherbourg, Rouen-Louviers-Austreberthe, Le Havre, Evreux, Dieppe, Ile-de-France, Meaux, Creil, Compiègne, Chauny-Tergnier-La Fère, Châlons-en-Champagne, Saint Dizier, Troyes and Auxerre. These 16 TRI are part of the 122 identified at national level and were formally identified as such by the Prefet $o$, the $27^{\text {th }}$ November 2012. It should be noticed that four of them (Ile-deFrance, Rouen, Le Havre and Troye) were specifically identifed for their national importance as flood on these territories would have national consequences [11].

Key feed-back from experience from that step are the following :

- the goal to set up a tool to prioritise public action is fully reached as the 16 TRI cover only 376 cities but include $70 \%$ of the population and $72 \%$ of the jobs at risk on the basin,

- while the concept of basin is sometime difficult to understand for some actors not familiar with water concepts, this more local scale to identify more local targets for public action helped in mobilizing actors. Indeed, the challenge remain to have a basin scale where relevant,

- as the data-set is based of existing knowledge, the exposure to floods (and flood maps used for that purpose) focus on zone were flooding is known to be an issue. For that reason, it will be important to consolidate the data set during the implementation of the first cycle of the Directive to ensure no locality, although not exposed to severe flood, has been missed,

- finally, identification of TRI was performed through geographical and numerical analysis of the territories. The consultation of local stakeholder ensured coherence was made with local organizations. When reviewing this exercise for the next cycle, the scale of global planning will be interesting to take further into account to confim if some TRI are actually distinct or if they actually represent a same territory (such as for Caen and Dives for instance). 


\subsubsection{Flood hazard maps and flood risk maps :}

As a response to article 6 of the directive, flood hazard and flood risk maps were produced on each of the 16 TRI from 2013 to 2014 . This was done in house and then submitted to the public. It consisted in producing different maps of $1 / 25000$ scale :

- flood hazard maps : they provide the area flooded as well as water depth for three scenarios (1) high probability of return from 10 to 30 years (2) medium hazard with return period from 100 to 300 years (3) extreme events with return period greater than 1000 years. Hazards are river flood, run-off and coastal floods and consequently some TRI are covered by several hazards maps. In the case of coastal flood, an additional scenario with climate change for the intermediate event is included ;

- flood risk maps : these maps take into account the key stakes at risk for each hazard scenario (as required by the flood directive) and among them constructed zones, zone of economic activity, key building for crisis management.

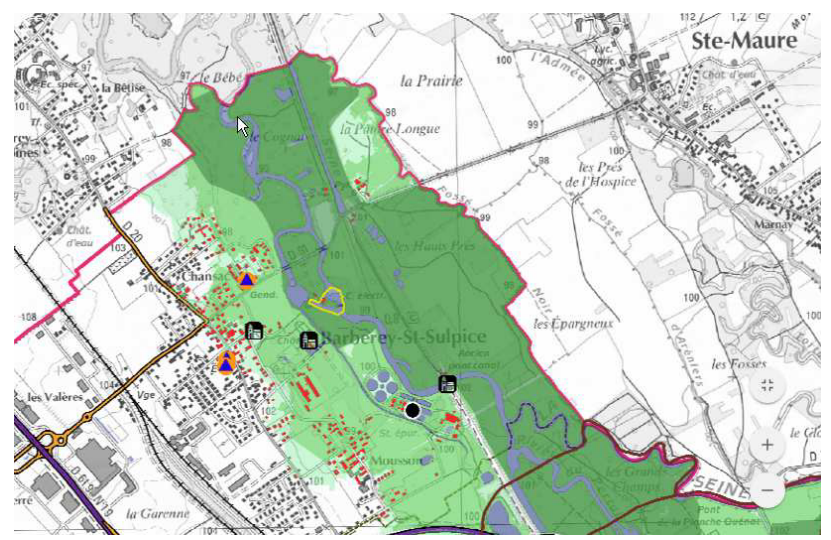

Figure 2. Extract from the risk map of Troye with the limit of the TRI (pink), the extension of the flood area for the three event (green), business area (yellow) and various stakes at risk with associated pictogram.

Key feed-back from experience are :

- these maps are the very first one that provide a consolidated view of hazard and risk in the key areas of the basin which is a key element for acquisition of missing data and an incredible basis to set up taylored strategies adapted to local challenges,

- the association of local stakeholders on local data that are meaningful to them was helpful as it lead to participation. The existence of 3 flood hazard maps was however difficult to understand for local authorities as these were used to one single event, ie. the one used for local planing maps. Explanation on what are these maps, what events they represent and what could be their used was essential and has contributed to develop the understanding of some representative of the local population mainly.

- the introduction of an extreme event scenario contributed to invite local actors to realize and possibly consider that flood risk is possible in areas previously considered as safe for shorter return period, or considered as such due to local planing maps. In addition, it help communication on the importance of preparing crisis even in zones known to be exposed but where planning and reducing vulnerability is not sufficient,

- the use of existing data somehow limited the exercise notably when combined alea could occur, in particular in estuaries and coastal zone. In addition, the way to account for levee (and their potentiality of breach) was source of debate with local actors. These aspects were particularly detailed in the communication of the maps and invite us to work further on these aspects in preparation of the maps revision. Integration of new hazard data after publication of the maps.

\subsubsection{Local strategies for management of flood risks (SLGRI)}

The SLGRI are expected for the end of 2016 but the work started as soon as the TRI were identified (ie. since 2013). The first step consisted in the identification of the most appropriate territory where actions should take place to reduce risk in the TRI as well as the strategic objectives to reach. It requires a strong implication of local stakeholders of the TRI but also from the basin where the TRI is located. The identification of the stategy perimeter was concluded by the end of 2014, when the territories for 15 SLGRI were adopted with key objectives (a single SLGRI is prepared for the neighbouring TRI of Caen and TRI of Dives). It sets up the ground for a complete development of the SLGRI with a target of adoption by the end 2016. In fact, not only the perimeter was decided but also the deadline for preparation of the SLGRI as well as key objectives for the strategy to develop. These key objectives are incorporated in the PGRI [12].

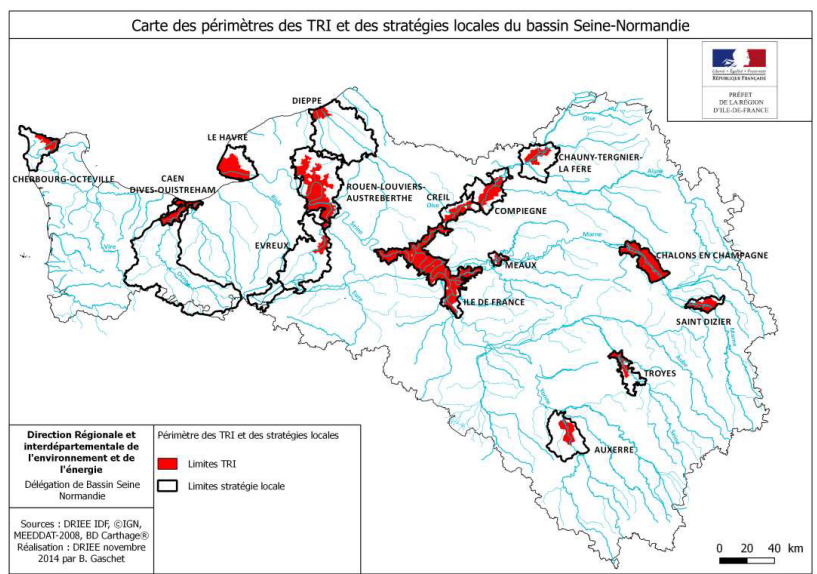

Figure 3. Map of the basin displaying the TRI (in red) and the extension of the SLGRI (in black).

Key feed-back from experience from that step are the following :

- the maturity and implication of local stakeholders varied a lot from one TRI to another, as well as the capacity to appreciate the importance to act a basin scale. Consequently, the support of the authorities on methodological aspects and go-between with actors was essential to make progress but not always self evident. It was also critical to accept a lower level of ambition at this stage, in term of basin coherence as well as objectives of 
the strategy (if key challenges of the TRI are addressed), if it allowed then the local communities to take over the steering of the SLGRi and if the area cover by the SLGRI set the ground for evolution at the end of the cycle;

- the explanation of the SLGRI added-value was a necessary, for territories newly involved in flooding management but also for territories that already add an action plan. In the later case, the strategy could appear as questioning again the current strategy in place although the SLGRI only put the action plan in context and perspective.

- political positions of local actors as well as possible financial implications somehow slowed the process of elaboration of the SLGRI. The new law GEMAPI (see below) was partly cause to this. Nevertheless, concertation between and with local actor to established an approproate governance was the key challenge during the SLGRI elaboration : it will indeed remain a major objective for most of the SLGRI during this first cycle of the Directive.

Finally, the absence financial support to hire dedicated staff to assist local communities did not help.

\section{ELABORATION OF THE PGRI}

\subsection{Key challenges identified}

As this was the very first elaboration of the PGRI, no return from experience actually existed. Nevertheless, the Seine-Normandy delagtio had also been significantly involved in the implementation of the water directive and some challenges were identified though not explicitely. The main challenges were :

- making sure that the PGRI would be focused on the key challenges that actually needed to be adressed during this first cycle ;

- making sure that the final document would be of reasonable size and could be accessible to all possible public in particular to non-specialists such as decision makers ;

- finding a good balance between technical work and more strategic or political exchange with stakeholders and avoiding a preparation of the PGRI by the authorities on their own;

- ensuring coherence with the implementation of the water directive and the maritime environment directive ; - ensuring the appropriate legal force of the PGRI ;

- carrying out the work in a limited time with limited dedicated staff.

\subsection{Method of elaboration}

A key decision to ensure bottom up approach was to set series of workshops associating member of the steering committee as well as the technical committee, with some invited experts, on

- knowledge on flooding and awareness on flood risks ;

- flood survey and forecast ;

- warning, preparedness and crisis management ;
- vulnerability and its reduction;

- taking flood hazard in planning ;

- dealing with hazard and common considerations with the water directive.

The table of content and successive drafts of the document were then prepared so that the PGRI is actually a prioritized strategy (and not an inventory of all possible actions) for implementation the flood directive on the basin. Thus, it was agreed by the steering group that the PGRI should contain not only objectives common to all the basin buy also dedicated objectives for the TRI that reflects the higher ambition on the TRI. Attention was paid to the added value of the PGRI with reference to existing tools. For that reason the PGRI was drafted as a framework to the flood management, using when mostly appropriate the various existing tools from either the flood risk management policies but also from the territories planning as well as water and aquatic environment management.

The later point was of specific importance as the PGRI has a given and specific legal force on some documents or decisions that should be compatible (ie. not contrary to) with the objectives of the PGRI. This is notably the case for :

- schemes (such as PAPI and SAGE) and individuals decisions of the administration in the domain of water (such as authorizations required for projects impacting water as large) ;

- the flood prevention plans, that in turn have compulsory effect on planning documents ;

- large scale planning schemes (SCOTs) as well as local planning map when the large scale are not available.

In the end, the results of the seminars and the use of existing tools was converted into a draft of the PGRI. It is organized around the three objectives of the SNGRI, and it was decided to introduce them by order of priority considering the global characteristics of the basin. A fourth objective was set, as it is a condition of success and transverse to the three others that is the mobilization of all stakeholder, thank to consolidation and development of risk awareness.

The draft also contained the key objectives for each SLGRI as well as the information related to the survey of the PGRI implementation.

Finally, an independent environmental impact assessment of the PGRI was carried out by a specialist consultant [13]. In its conclusion, it estimated that the PGRI was prepared in a concerted manner and in a continuous improvement approach ; it also estimated that the impact of the PGRI were acceptable and that attention should be paid to action that will be carried out locally to implement the PGRI. Interestingly enough, it identified the effort put into articulating the tools related to flood, water, coast and see as well as planning to be a strength of the PGRI.

\subsection{Submitting the PGRI to stakeholder}


The PGRI was submitted to the public from the $12^{\text {th }}$ December 2014 to the 18 th June 2015. This consultation was made simultaneously with the consultation of plan for the water directive and for the maritime environment directive. To make the consultation more interactive a questionnaire was made available with 6 questions for the flood directive and 10 for the water directive. 377 responses were received, mainly from person leaving out of risk areas, who considered they are poorly informed on risks as well as how to act in case of flood.

The PGRI was also submitted to the stakeholder directly concerned (cities, economic chambers representing agriculture, industry and small businesses as well as official organizations dealing with waters, planning) from the $15^{\text {th }}$ January to the $15^{\text {th }}$ May 2015. 1285 PGRI were sent and 185 responses were received, with $81 \%$ of them positive, including comments or recommendation for improvement. Criticism mainly came from the agriculture sector that considered the plan to prescriptive and protective of flood plains. Other criticism were related to the subject of planning and urbanism considered mainly excessively or not enough prescriptive. Some of the criticism were not adressed to the PGRI itself but were related to local flooding maps. All these elements are presented in a public report [14] as well as the way all these feed-back have been adressed.

The steering group was largely associated to that important task for ket decisions and detailed traceability was put in place in case of future legal action against the PGRI. The key modifications implemented while preparing the final draft can be presented as follows. :

- the $4^{\text {th }}$ objective was strengthened to deal not only with risk awareness but also with the development a reinforced governance ;

- the case of coastal territories is refined,

- most of editorial comment concerned either the articles related to flood plain or planning ;

- monitoring of the PGRI implementation was consolidated taking into account work that was carried out in parallel.

\subsection{Content of the PGRI}

Finally the PGRI that was approved on the 7 December and published on the 22th December 2015 contains :

- a preamble presenting :

- the framework of the PGRI elaboration,

- the diagnosis of the basin territories,

- the overall strategy at the scale of the basin, - the general objectives for the basin :

- reduction of territories vulnerability,

- $\quad$ action on hazard to reduce cost of damages ;

- significant reduction of the time required to come back to normal in flooded zones,

- mobilization of all stakeholder to consolidate the governances and risks awareness.

- the specific objectives for the SLGRI :
- with an introduction explaining the connection between the PGRI and the SLGRI,

- dedicated objectives for each SLGRI, - a chapter on implementation of the PGRI :

- giving details of the connection with the ORSEC plan and their maps,

- indicators of PGRI implementation,

- the connection between flood and water directive in the basin,

- the use of flood maps.

For practical use of the PGRI, articles applicable to all the basin, only on TRI or common with the water directive plan are presented with a self explanatory pictogram.

\section{STRATÉGIE DE GESTION DES RISQUES D'INONDATION}

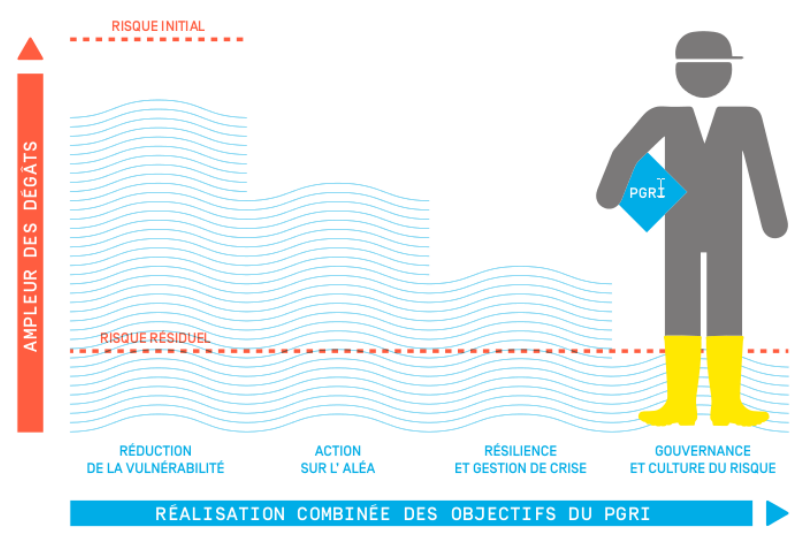

Figure 4. illustration of the PGRI approach showing the action through the combined objectives of the PGRI (in blue, including reduction of vulnerability, action of hazard, resilience and crisis management, governance and culture) and the importance of hazard from initial hazard to residual hazard (just below the rubber boots...)

It set 63 clauses with a legal power of compatibility or recommendation that are either applicable on all the basin, on the TRI only. 12 of them are exactly common with the water directive plan. The PGRI also set in place 10 indicators to survey the implementation of the PGRI.

The document is 155 pages long, with 75 pages providing the specific objectives of the SLGRI (ie. 80 pages generic to the basin containing 10 diagrams). The PGRI is available electronically with all technical and procedure documentation and it was sent to each of the 1285 stakeholders by post.

\section{FEED-BACK FROM EXPERIENCE OF THE PGRI PREPARATION}

\section{1 on the PGRi itself}

The preparation of the PGRI would not have been possible without the constant commitment of the members of the steering committee as well as the technical committee. Strong leadership including 
reminding to the initial editorial approach (short, understandable, prioritized) was also a condition of success.

The production of indicators was difficult and a methodical approach combining a refined knowledge of existing or accessible data as well as construction of questions to evaluate the PGRI was required. The importance and complexity of that task was underestimated, which required a specific work in parallel of the public and stakeholder submission, with a dedicated task group. It is now time to measure those indicators to set a reference in 2016 and to set in place an operational procedure for the regular determination of these indicators.

Surprisingly enough, the involvement of planning experts was less than the other groups of actors. Only 5 responses over the 129 SCOTs during the submission of the PGRI and none from the public offices for planning and architecture. Action has been taken immediately at the beginning of 2016 thanks to exchange with their national federation. Further action is required to develop a common languages and explain approaches to put the flood risk as an input data to any planning activity, not a constraint.

Considering financial aspects, no global evaluation of the PGRI cost is available yet. It is indeed difficult at this stage, as costing the PGRI would require a detailed analysis of its implementation in the basin, notably through the SLGRI and the relevant operational actions which are currently in preparation. Costing will also be sensitive to the level of ambition that is a local decision. A form of costing will however be essential to put the ambition in context as well as to challenge financing possibilities that are currently available, and in turn adjust both ambition and financing. Furthermore, and in connection with the EPRI, it is essential to put face to face the cost of implementing the PGRi with the cost of potential risk of non action. For Ile-de-France only, the cost of the historical flood from 1920 is estimated to 3 to 30 billion euros for direct risk, with a reduction of the nation gross income from 1.5 to 58.5 billion euros [10]

On the short term, the Seine-Normandy delegation is preparing a digest of the various sources and conditions to finance flood management to provide a comprehensive kit for local stakeholders and decision makers.

From a more positive perspective, stakeholders consider the PGRI as a comprehensive document, with clear priorities and that make appropriate use of existing tools. It can also be pointed out that the approval of the PGRI was not sued.

At this stage, priority is given to provide guidance to implement the PGRI (in particular with reference to vulnerability of the territories) as well as communication on good practice (in particular with reference to culture awareness and education thanks to a Grand Prix specific to the basin). The governance, at the basin scale with reference to the PGRI, has already evolved from production to implementation. Consequently, the steering committee will invite witnesses to share their experience to identify forces and challenges on the different objectives of the PGRI. It will allow local stakeholder to express their expectation, and the steering committee to set all actions to facilitate implementation of the PGRI. Seminar dedicated to stakeholder are also plan to allow exchange of experience between them : the first one being on the articulation between local strategy and action plan.

\subsection{Legal evolutions on local authorities obligation during the preparation the PGRI}

In 2014, a major legal change occur as the law created a new and compulsory responsibility for local authorities through the law $\mathrm{n}^{\circ} 2014-58$ of the $27 \mathrm{th}$ January 2014 on modernisation de l'action publique territoriale et d'affirmation des métropoles (MAPTAM), ie. on modernization of local public actions and for the reinforcement of metropolis. This responsibility includes the four following activities : hydraulic works in a river basin, maintaining and modifying river courses, protection and restoration of river courses and protection against coastal and river flood. The law also creates an optional tax but dedicated only to the four activities above. As local authorities are also legally in charge of planing, planing activities should be in better connection with managing aquatic environment and prevention of flood hazards.

The aim of the present paper is not discuss in detail the forces and challenges of the MAPTM law. However, the authors would like to stress some interactions with the PGRI and its implementation :

- the NOTRE law of august 2015 postponed the effect from the $1^{\text {st }}$ January 2016 , ie. year before the adoption of the SLGRI, to 2018, ie. one year after the SLGRI. At this stage, it is difficult to say if this postponement has had an effect on the mobilization of local stakeholder in the elaboration of the SLGRI. In any case, this set a favorable ground for SLGRI, after 2018, as local authorities will be in charge of flood prevention and consequently directly concerned by the SLGRI on their own territories ;

- the MAPTAM law allows local authorities to join into public entities either to carry out local work or to coordinate their activities and to carry out programs of common interest. This two scales (local versus more global) are totally in accordance with the approaches of the PGRI that identifies complementary scales of action : local on vulnerabilty reduction and defense work, as well as global to reduce hazard and delay water in the upstream. These groupments also offer positive perspective for implementation of the PGRI, and wider for flood prevetion as they allow to share professional staffs and consequently allow a more efficient prevention of flood hazard.

\section{Acknowledgment}

The authors would like to thank their colleagues whoc have been previously involved in the implementation of the flood directive and in particular, Jean-Marie 
Quemener, Jean-Michel Helmer and Anne-Sophie Leclere.

\section{References}

1. Comité de bassin Seine Normandie (2015). Schéma directeur et d'aménagement et de gestion des eaux (SDAGE) 2016-2021 du bassin de la Seine et des cours d'eau côtiers normand, $331 \mathrm{p}$

2. Préfecture d'Ile-de-France (2011). Evaluation préliminaire des risques d'inondation 2011 du basin Seine-Normandie, $546 \mathrm{p}$

3. Drobenko B. (2015). La loi sur l'eau de 1964 : bilans et perspectives Ouvrage collectif sous la direction de Bernard Drobenko, Editions Johanet, 208p

4. de Linares L, Morelle C, Pradier V, Wihiot J-P (1999). L'aménagement du territoire : 1958-1974. Actes du colloque tenu à Dijon les 21 et 22 novembre 1996, Editions L'Harmattan, p. 340

5. Ministère de l'écologie, du développement durable et de l'énergie (2014). Stratégie nationale de gestion des risques d'inondations, www.developpementdurable.gouv.fr $24 \mathrm{p}$

6. République française (2010). Loi no 2010-788 du 12 juillet 2010 portant engagement national pour l'environnement, Journal officiel de la république française $126 \mathrm{p}$

7. A Dufay (2012). Plan Loire Grandeur nature, Symposium européen : Symposium sur les problèmes actuels de la protection contre les inondations du 28 au 30 mars 2012, Paris-Orléans, 6 p

8. DRIEE (2007). Plan Seine. Préfecture d'Ile-deFrance, $123 p$

9. AFEPTB (2013). Établissement public territoriaux de bassin, www.asso.eptb.fr, $47 \mathrm{p}$

10. OECD (2014). Seine Basin, Ile-de-France : Resilience to Major Floods, OECD Reviews of Risk Management Policies, 27p

11. MEDDE (2012). Arrêté du 6 novembre 2012 établissant la liste des territoires dans lesquels il existe un risque d'inondation important ayant des conséquences de portée nationale, Journal officiel de la République Française $n^{\circ} 0276$ du 27 novembre 2012, p 5-6

12. Préfecture de région Ile-de-France (2014). Arrêté fixant la liste des stratégies locales à élaborer pour les territoires à risque important d'inondation $d u$ bassin de la Seine et des cours d'eau côtiers normands, leurs périmètres, les délais de réalisation et leurs objectifs, Pérecture de région Ile-de-France, $2 \mathrm{p}$

13. P Cauche, D Leguy (2014). Rapport environnemental du PGRI du Bassin SeineNormandie, ADAGE consultants, 141p

14. DRIEE (2015). Déclaration environnementale au titre de l'article L. 122-10 du code de l'environnement relative au Plan de Gestion des Risques d'Inondation (PGRI), du bassin SeineNormandie, Paris, $7 \mathrm{p}$ 